\title{
Degradation of trace aqueous 4-chloro-2-nitrophenol occurring in pharmaceutical industrial wastewater by ozone
}

\author{
${ }^{1 * P .}$ Gharbani; ${ }^{1}$ M. Khosravi; ${ }^{2}$ S. M. Tabatabaii; ${ }^{3}$ K. Zare; ${ }^{4}$ S. Dastmalchi; ${ }^{2}$ A. Mehrizad \\ ${ }^{1}$ Department of Chemistry, North Tehran Branch, Islamic Azad University, Tehran, Iran \\ ${ }^{2}$ Department of Chemistry, Ahar Branch, Islamic Azad University, Ahar, Iran \\ ${ }^{3}$ Department of Chemistry, Science and Research Branch, Islamic Azad University Tehran, Iran \\ ${ }^{4}$ School of Pharmacy, Tabriz University of Medical Sciences, Tabriz, Iran \\ Received 5 October 2009; $\quad$ revised 10 December 2009; accepted 5 February 2010; avaiable online 1 March 2010
}

\begin{abstract}
Degradation of 4-chloro-2-nitro phenol by ozonation in aqueous solution was studied in a semi batch reactor under constant ozone dosage and variable $\mathrm{pH}$ conditions. The effectiveness of the process was estimated based on the degree of conversion of 4-chloro-2-nitro phenol. It was observed that ozonation is more effective at alkaline reaction of medium than other conditions. The degree of conversion achieved (at the first 5 minutes of the process)at $\mathrm{pH}$ 9 was $99.64 \%$ compared to $99.03 \%$ and $77.35 \%$ at $\mathrm{pH} 7$ and 3, respectively. Another parameter used to quantify the 4chloro-2-nitrophenol during ozonation was the pseudo first order rate constant $k$ [ $\mathrm{min}^{-1}$. Results showed that the rate constant of the process was approximately much higher at the alkaline $\mathrm{pH}$ compared to acidic ones. A considerable improvement in chemical oxygen demand removal was observed at $\mathrm{pH}$ above 7 . At $\mathrm{pH} 9$, the reduction in chemical oxygen demand at the end of the process reached $56.9 \%$. The degree of organically bounded nitrogen conversion to nitrate was higher at $\mathrm{pH}$ 3. Of the total organic carbon reduction, $15.89 \%$ was observed at $\mathrm{pH}$ 9. The 4-chloro-2-nitro phenol degradation intermediate products were analyzed by mass- spectrometry. The main intermediate product was chlorophenol.
\end{abstract}

Keywords: Chemical oxygen demand; Degradation; Kinetic; Mineralization; Total organic carbon

\section{INTRODUCTION}

There is growing public concern about the widespread contamination of surface and groundwaters by various organic compounds over the past several decades (Utsumi et al., 2003). Industrial use of phenol and its derivatives over the past decades had led to severe environmental pollution. Out of this, around 190.3 ton per month constitute phenolic wastes disposed mainly by petrochemicals, pharmaceuticals and polymer industries (Zareen and Anjaneyulu, 2005). A large number of organic contaminants are hazardous even at low concentration levels and stringent regulations are being enforced, especially in the industrialized nations for both conventional and nonconventional pollutants. Therefore, more effective methods are necessary for treating contaminated water and wastewater to meet the challenges (Giri et al.,

*Corresponding Author Email: parvingharabani@yahoo.com Tel.: +98914 107 6447; Fax: +98411 3341189
2008).The concentration of these chemical compounds is usually below $1 \mathrm{ppm}$ in seawater and half in river water without dilution capacity. This is in agreement with the regulation dealing with the evolution of phenolic compounds to the environment, regulated by different governmental agencies (Villasenor et al., 2002). Nitroaromatic compounds are used in many industrial processes, including the preparation of pesticides, explosives, textiles and paper. Therefore, these compounds are often detected as water pollutants as a result of their release in industrial effluents (Beltran $e t$ al., 1998; Sarasa et al., 1998). If these effluents are discharged into water without proper treatment, they are hazardous to humans and the environment (Song et al., 2007). 4-Chloro-2-nitro phenol (4C2NP) is known to cause severe pollution problems in aquatic environments. 4C2NP is widely used in agriculture and related industries as an ingredient in pesticides and 
insecticides. However, it is highly toxic because it is refractory and hard to remove by conventional biological treatment processes. Therefore, it is highly recommended to either conduct it very effectively, to less harmful intermediates or complete mineralization. In the last years, a wide variety of methods have being applied to the mineralization (i.e. conversion to $\mathrm{CO}_{2}$ and inorganic ions) of recalcitrant organic contaminants in wastewaters (Sauleda and Brillas, 2001). Advanced oxidation processes (AOPs) have been widely investigated and proved to be a promising method for the elimination of toxic and bio-resistant organic and inorganic compounds (Legube and Karpel, 1999; Gunten, 2003). In principle, AOPs generate very powerful and non-selective oxidizing agent, the hydroxyl radical $\left(\mathrm{OH}^{\circ}\right)$ for the destruction of refractory and hazardous pollutants found in groundwater, surface water and industrial wastewaters (Gharbani et al., 2008). Most nitro and/or chloro-aromatic compounds have been proven to be toxic and bio-resistant and their removal from water has been investigated using AOPs such as ozonation, catalytic ozonation, UV photolysis, $\mathrm{H}_{2} \mathrm{O}_{2}-\mathrm{UV}$ and electrocatalysis (Shen et al., 2008; Madukasi et al., 2010). Samarghandi et al., (2007) studied the effect of photo catalysis/ hydrogen peroxide processes for the removal of phenol, lead and cadmium by three different pHs of 3.5, 7 and 11. Ozone $\left(\mathrm{O}_{3}\right)$ has been found to be an effective oxidizing agent for the removal of many organic pollutants from water (Benitez, 2003). Ozonation is very effective in treating wastewaters containing phenolic compounds (Wu et al., 2000). Ozone has been recognized for nearly a century for its powerful ability to disinfect water (Panjeshahi and Ataei, 2008). Ozone is an attractive and increasingly important method for the degradation of organic pollutants in aqueous solution (Huang et al., 2005). Ozonation treatment, both in indirect and direct reaction modes, has been proved effective in degrading of recalcitrant organic contaminants. Direct ozonation has the advantage of high selectivity, which warrants its specific application in killing microorganisms, oxidizing minerals, as well as organic contaminants that have reactive functional groups in water treatment. It is the selectivity that a low ozone dosage is usually sufficient to achieve hygienic and chemical goals of water purification (Hoigne, 1998). Many researchers (Hoigne and Bader, 1983; Kuo and Huang, 1995; Benitez et al., 2000) have studied ozonation of halogenated organic compounds in aqueous media. It has been shown that the dissociation of phenols and substituted phenols leads to a much greater reactivity with ozone (Hoigne and Bader, 1983) thereby making them more susceptible to treatment (Graham et al., 2003). Ozone has an ability to oxidize various organic contaminants in water. Pesticidesynthesis industries generate spillages, which contain many toxic and non-biodegradable compounds that remain in the environment even after the waste products have been subjected to a conventional processing system. Ozonation of organic matter can lead to the production of by-products (Andrews et al., 1993), which are suspected to be public health concerns, like aldehydes, phenols, aromatic acids, etc. Organic compounds present in the wastewater react with ozone in both molecular form and as hydroxyl radicals to form oxygenated first ozonation by-products (FOBPs) (Legube et al., 1981). Reaction rate constants for the ozonolysis of organic compounds as well as for free radical reactions are available but were measured at specific conditions (Stockinger et al., 1995). Saritha et al., (2007) studied the efficiency of AOP'S methods on degradation of 4-chloro-2-nitrophenol (UV, $\mathrm{H}_{2} \mathrm{O}_{2}$, Fenton, $\mathrm{UV} /$ Fenton, $\mathrm{UV} / \mathrm{TiO}_{2}, \mathrm{UV} / \mathrm{H}_{2} \mathrm{O}_{2}$ ) and concluded that among them, UV/Fenton was the most effective in partial mineralization of 4C2NP. Goi et al., (2004) resulted that ozonation can be applied as a very effective treatment method for detoxification and biodegradability improvement of NPs containing wastewater. The achieved biodegradability improvement and detoxification of treated NPs supports the potential use of ozonation to improve the capacity of conventional biological treatment to remove these toxic and poorly biodegradable compounds. Diwani et al., (2009) found that 2,4,6-trinitrotoluene and red water effluent were mineralized by ozonation and multi-stage ozonation biological treatment. This study aims to investigate the ozonation of 4-chloro-2-nitrophenol in aqueous solutions at pHs 3, 7 and 9. A part of work is focused on the kinetic analysis of the data collected during ozonation experiments performed in a semi batch reactor. The experiments was conducted in Departmentof Chemistry, North Tehran Branch, Islamic Azad University, during 2008-2009.

\section{MATERIALS AND METODS}

The chemical 4-chloro-2-nitrophenol (4C2NP) $\left[\mathrm{C}_{6} \mathrm{H}_{14} \mathrm{NO}_{3} \mathrm{Cl}, \mathrm{M}=173.56\right.$ ] (Fluka Co., Germany) was used as the probe to investigate the catalytic ozonation 
process. A stock solution of 4C2NP was prepared in deionized water (Millipore Milli-Q water) at a concentration of approximately $69 \mu \mathrm{M}(12 \mathrm{mg} / \mathrm{L})$. All other chemicals such as sodium thiosulphate, potassium iodide, etc. were reagent grade and were supplied by Merck Company, Germany. All glassware was soaked in chromic acid, then rinsed with tap water and distilled water. All solutions were prepared using deionized water (Ultrapure system, Barnsterd).

\section{Experiment processes}

All experiments were conducted in a $2000 \mathrm{~mL}$ Pyrex glass reactor of $250 \mathrm{~mm}$ length and $150 \mathrm{~mm}$ diameter. Ozone gas was generated from the Ozone generator Model X-200 (Baku, Azerbaijan) with adjustable flow rates and driven by pure oxygen. A flow regulator was used to control the oxygen pressure to the inlet of the ozone generator. The Ozone/oxygen mixture from the outlet of the Ozone generator was transferred via a Teflon tube and then fed into the contact glass through a porous gas diffuser located at the bottom of the glass, as shown in Fig. 1.

Exactly $1000 \mathrm{~mL}$ of 4C2NP solution (12 mg/L) was used during each semi-batch ozonation. A magnetic stirrer was worked with the gas diffuser to provide sufficient recirculation of the aqueous ozone-4C2NP mixture and to facilitate ozone gas transfer. Exhaust gas was directed to an Erlenmeyer flask containing KI solution in order to measure the unreacted ozone by an iodimetric method. The reactor was placed in an air-conditioned laboratory at $23 \pm 2{ }^{\circ} \mathrm{C}$. $\mathrm{HCl}(1 \mathrm{~N})$ or $\mathrm{NaOH}(1 \mathrm{~N})$ solution was used to control the $\mathrm{pH}$ level during the reaction. Samples were withdrawn $\left([4 \mathrm{C} 2 \mathrm{NP}]_{0}=12 \mathrm{mg} / \mathrm{L}\right)$ at different intervals to determine the residual concentration of 4C2NP and the contact time was $30 \mathrm{~min}$. Samples ozonated for 1 , 2, 5, 10, 15, 20 and $30 \mathrm{~min}$, were measured by both the photometric and the HPLC methods. The two methods gave similar results and the differences ranged from $3.1 \%$ to $4.8 \%$. The oxidation reaction was quenched by the addition of a small amount of sodium thiosulphate.

\section{Measurement methods}

The progress in the degradation of 4C2NP was recorded with a high performance liquid chromatograph (Shimadzu, SCL-6A, Japan) equipped with UVspectrophotometer (Shimadzu, SPD-6AV, Japan). A reverse phase column, filled with $5 \mu \mathrm{m}$ Separon C18 (Waters, USA), was $150 \mathrm{~mm}$ in length and $4.6 \mathrm{~mm}$ in diameter. The isocratic method with a solvent mixture of $70 \%$ acetonitrile and $30 \%$ deionized water with a flow rate of $1 \mathrm{~mL} / \mathrm{min}$ were used. The retention time for 4C2NP was $4.11 \mathrm{~min}$.

Total organic carbon (TOC) was measured with Shimadzu TOC-5000 analyzer equipped with an autosampler (ASI-5000) and platinum based catalyst. The carrier gas was synthetic air at the rate of $150 \mathrm{~mL} / \mathrm{min}$. The samples were acidified to $\mathrm{pH}<4$ before being sent to TOC analyzer to ensure that inorganic carbon would be released from the solution as $\mathrm{CO}_{2}$. Sample chemical oxygen demand (COD) determinations were made by the HACH's COD method using a COD reactor (HACH Co.) and a direct reading spectrophotometer (DR/5000U, HACH Co). Absorbance was measured at a wavelength of $234 \mathrm{~nm}$ (basic and neutral) and $220 \mathrm{~nm}$ (acidic) using a Shimadzu UV-2501 recording spectrophotometer. The solution $\mathrm{pH}$ was measured with a $744 \mathrm{pH}$-meter ( $\Omega$ Metrohm). The concentration of nitrate ions formed as a result of organically bounded nitrogen mineralization was measured with a spectrophotometer (HACH, DR/4000 $\mathrm{U})$ at $275 \mathrm{~nm}$. Intermediates were analyzed by mass spectroscopy (MS) using a Waters 3100 Mass Detector.

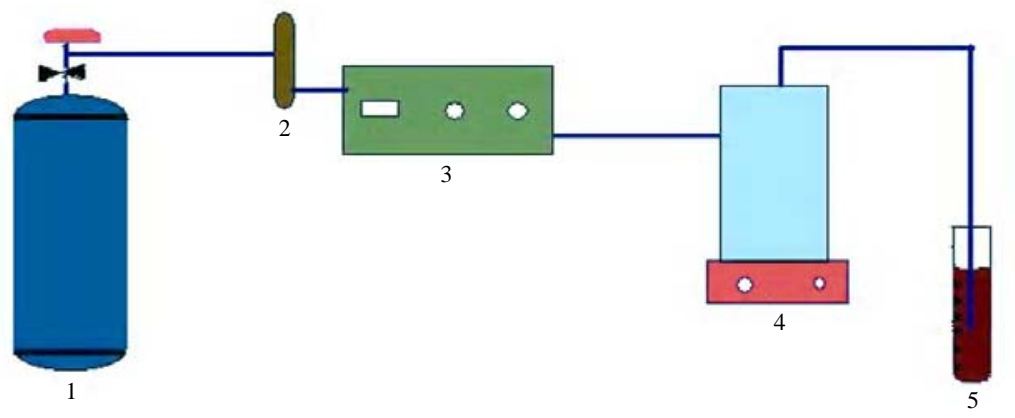

Fig. 1: Schematic diagram of experiment system 1-Pure oxygen, 2) Desiccator, 3) Ozonator, 4) Magnetic stirrer, 5) Reactor, 6) Ozone detector (KI) 


\section{RESULTS AND DISCUSSION \\ Effect of $p H$}

The influence of $\mathrm{pH}$ on the effectiveness of 4C2NP degradation by ozonation is shown in Fig. 2. Further effect of $\mathrm{pH}$, the degradation experiments were carried out at $\mathrm{pH}$ values of 3,7 and 9 . The degradation rate increased as the $\mathrm{pH}$ increased from 3 to 9 . In general, the $\mathrm{O}_{3}$ molecule itself was one of the main reactive species under acidic conditions, so the degradation of 4C2NP exhibited low efficiency (Kasprzyk-Hordern et al., 2003).As the solution became more basic, the rate of $\mathrm{O}_{3}$ decomposition to secondary oxidants, such as hydroxyl radicals, increased (Muthukumar et al., 2004). The obtained results indicate that the process effectiveness increases significantly at $\mathrm{pH}$ above 7 , which is a result of an enhanced Ozone decomposition and the shift towards radical type reaction at $\mathrm{pH}>7$. The optimal pH during these experiments was 9.

\section{Ozonation at $\mathrm{pH} 3$}

At $\mathrm{pH}=3$, free radical formation is very low; therefore, radical reactions are expected to be negligible, whereas direct molecular ozonolysis should be highly predominant. The oxidation of aromatic rings, therefore, seems to be provided by ozonolysis of double bonds. Only $77.35 \%$ of 4C2NP was removed after 5 min of ozonation (Fig. 2).

\section{Ozonation at $\mathrm{pH} 7$}

At this $\mathrm{pH}$, ozonolysis and $\mathrm{OH}^{-}$radical reactions are expected to be equally important. Concentration

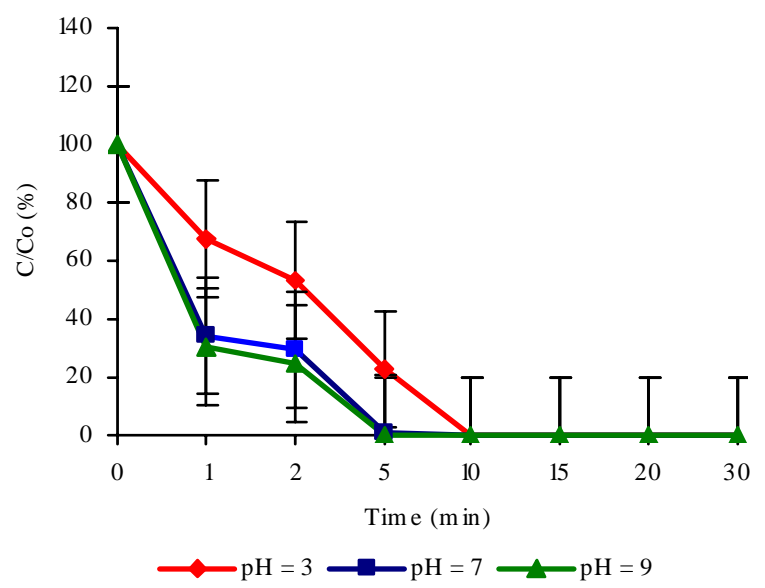

Fig. 2: Decomposition of 4C2NP by ozonation at different pHs $\left[\mathrm{O}_{3}\right]_{o}=5.64 \mathrm{mg} / \mathrm{L} ;[4 \mathrm{C} 2 \mathrm{NP}]_{o}=12 \mathrm{mg} / \mathrm{L}$ profiles of the 4C2NP is shown in Fig. 2. Although the total initial concentration of the 4C2NP was similar (12 $\mathrm{mg} / \mathrm{L})$ to those of at $\mathrm{pH} 3(12 \mathrm{mg} / \mathrm{L})$, the degradation period was shorter ( $99.03 \%$ at first $5 \mathrm{~min}$ ), caused by the effect of additional radical reactions. By $30 \mathrm{~min}$ ozonation, $99.77 \%$ of 4C2NP was degraded.

\section{Ozonation at $\mathrm{pH} 9$}

At high $\mathrm{pH}$, the formation of ${ }^{\circ} \mathrm{OH}$ radicals is fast. Ozonolysis is expected to be negligible because of fast Ozone usage for radical formation. Fig. 2 shows that the degradation of 4C2NP was $90.83 \%$ up to $30 \mathrm{~min}$ of ozonation. Fig. 2 shows the disappearance of 4C2NP at various initial $\mathrm{pH}$ levels during the ozonation. As shown, the rates of disappearance of 4C2NP were similar both at neutral and basic conditions. 4C2NP undergoes acid-base equilibrium., ii.e., $\mathrm{C}_{6} \mathrm{H}_{4} \mathrm{NO}_{3} \mathrm{Cl}=$ $\mathrm{H}^{+}+\mathrm{C}_{6} \mathrm{H}_{3} \mathrm{NO}_{3} \mathrm{Cl}^{-}$. At $\mathrm{pH} 3$ both $\mathrm{C}_{6} \mathrm{H}_{4} \mathrm{NO}_{3} \mathrm{Cl}^{3}$ and $\mathrm{C}_{6} \mathrm{H}_{3} \mathrm{NO}_{3} \mathrm{Cl}^{-}$are equally abundant, whereas at higher $\mathrm{pH}, \mathrm{C}_{6} \mathrm{H}_{3} \mathrm{NO}_{3} \mathrm{Cl}^{-}$becomes the predominant species. For an ionizable organic compound, the reaction rate of $\mathrm{O}_{3}$ is typically faster with the charged anion form than with the conjugate acid (Hong and Zeng, 2002); however, the expected increases in reaction rate according to abundantly of $\mathrm{C}_{6} \mathrm{H}_{3} \mathrm{NO}_{3} \mathrm{Cl}^{-}$resulted at higher $\mathrm{pHs}$, were observed at $\mathrm{pH} 7$ to 9 .

\section{Comparative discussion of semi-batch experiments}

The time for degradation of 4C2NP was comparable in all experiments despite $\mathrm{pH}$ values but constant ozone supply rates. The three further experiments at

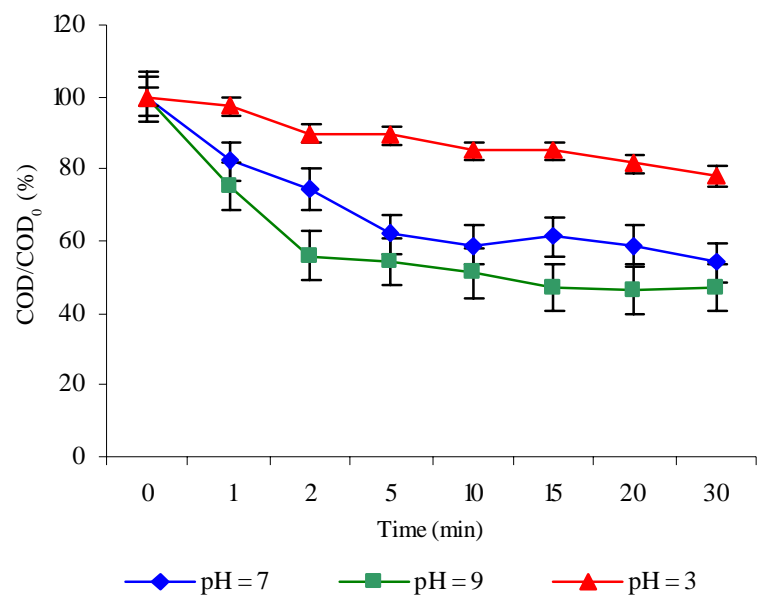

Fig. 3: The effect of the time of ozonation on COD abatement at varying pHs. $[\mathrm{O} 3]_{o}=5.64 \mathrm{mg} / \mathrm{L} ;[4 \mathrm{C} 2 \mathrm{NP}]_{o}=12 \mathrm{mg} / \mathrm{L}$ 
$\mathrm{pH}$ values of 3, 7 and 9, confirms the trends reported. The shortest degradation period was obtained at $\mathrm{pH} 9$. The additional effects of ${ }^{\circ} \mathrm{OH}$ radical reactions at $\mathrm{pH} 9$ presumably led to higher overall elimination rates than at lower $\mathrm{pH}$ values. Low $\mathrm{pH}$ suppresses the formation of radicals. High $\mathrm{pH}$ promotes radical formation, but at the same time also promotes ozone self-decomposition. This decomposition could not be compensated by the increased radical reactions with organic pollutants. Fig. 3 shows the disappearance of COD content throughout the ozonation process. The changes of COD content in the reaction media, subjected to ozonation at $\mathrm{pHs}$ of 7-9, were similar, all showing a gradual decrease as ozonation progressed. The decreases reflected the gradual reduction of oxidizable organics remaining in the reaction medium, which reflected the progress of mineralization driven by continually added ozone. For the 4C2NP studied at $\mathrm{pH}=9.0$, Fig. 3 shows much decreases of COD within 5 min of ozonation. As it is known, the oxidation treatments were also effective in reducing the $\mathrm{COD}$ of solution. At $\mathrm{pH} 9$, increases in the ozonation time lead to increases in COD removals from $29.2 \%$ (1 $1 \mathrm{~min}$ ) to $56.9 \%$ (30 $\mathrm{min}$ ). It is also clear from the data (Fig. 3), increasing trend of COD over time of ozonation is not linear. Initially, the rate of COD degradation is rapid, but the rate decreases with time. This can probably be ascribed to the fact that some organic compounds are more susceptible to oxidation than others, while some are only partially oxidized.

$\mathrm{NO}_{3}{ }^{-}$was detected from the beginning of the reaction. During the reaction process, the increased concentration of nitrate ion is shown during the ozonation (Fig. 4). It was likely that nitro-groups were displaced by ${ }^{\circ} \mathrm{OH}$, with a variety of phenols being

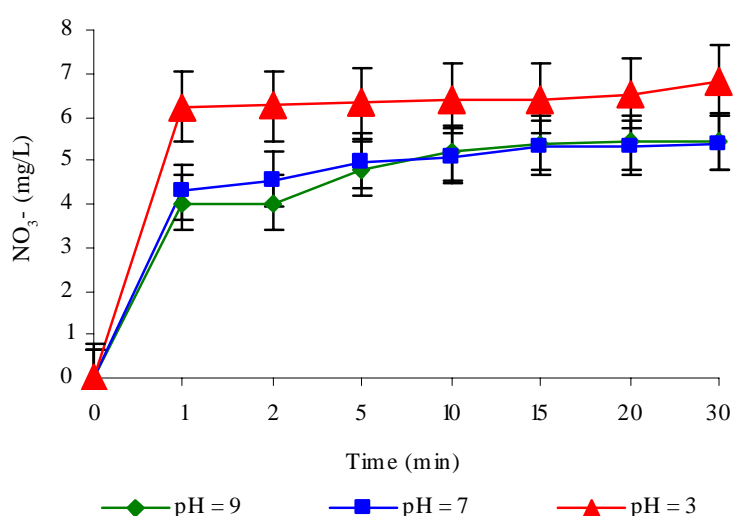

Fig. 4: Measured concentration of $\mathrm{NO}_{3}^{-}$throughout ozonation of $4 \mathrm{C} 2 \mathrm{NP}$ at different pHs, $[\mathrm{O} 3]_{o}=5.64 \mathrm{mg} / \mathrm{L} ;[4 \mathrm{C} 2 \mathrm{NP}]_{o}=12 \mathrm{mg} / \mathrm{L}$ generated by ${ }^{\circ} \mathrm{OH}$ attack on 4C2NP. Fig. 4 shows the concentration profiles of $\mathrm{NO}_{3}^{-}$ions produced. The curves for $\mathrm{NO}_{3}^{-}$were obtained from the decrease of aromatics with the assumptions that the initial degradation step was denitration and no nitrosubstituted intermediates were produced. Nitro group substituents are removed first as nitrite that is finally oxidized to nitrate. Eliminated nitro substituents were found as $\mathrm{NO}_{3}^{-}$. In addition, it is also possible the existence of stable nitrogen-containing compounds in the final degraded solutions, especially after direct ozonation. Nitrate formation was quite fast at the initial stage of ozonation then it was decreased (Fig. 4).

\section{Mineralization extent of $4 \mathrm{C} 2 \mathrm{NP}$}

The destruction of TOC is the ultimate goal of advanced oxidation processes (Alaton and Balcioglu, 2001). Fig. 5 shows the total mineralization of 4C2NP during ozonation. At the beginning of ozonation process, the concentration of 4C2NP slowly decreased (Fig. 2), and then 4C2NP degradation became constant after $10 \mathrm{~min}$. This is not consistent with 4C2NP elimination rate, indicating only part of 4C2NP was mineralized and thus presumably some degradation intermediate products were formed during the ozonation of 4C2NP.

TOC was calculated by summing the carbon of all analyzed organic compounds. Carbon mineralization rate was very slow during the degradation of 4C2NP by ozonation at the present conditions (Fig. 5). In ozonation, TOC barely decreases with time in many cases (Beltran et al., 1998). The overall TOC elimination was less at acidic $\mathrm{pH}$. Ozonation of 4C2NP resulted in unsubstantial reduction of TOC values. The degree of

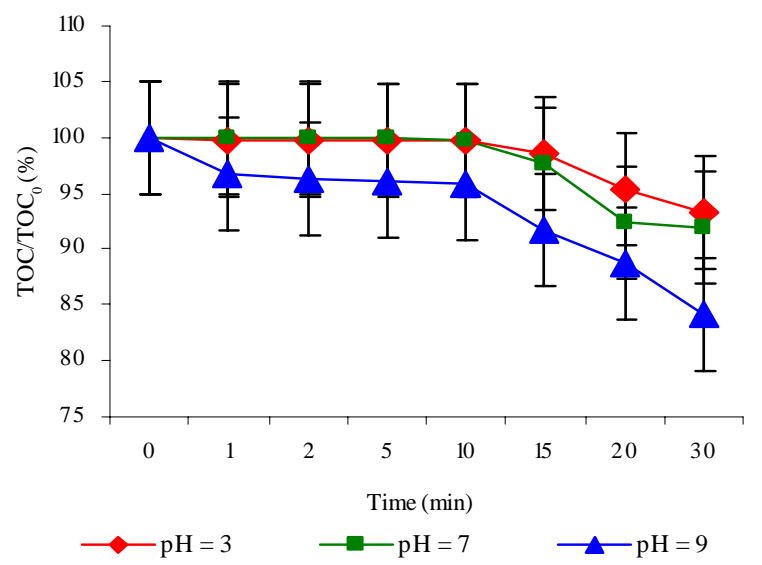

Fig. 5: Comparison of $\mathrm{pH}$ for TOC removal during ozonation $[\mathrm{O} 3]_{o}=5.64 \mathrm{mg} / \mathrm{L} ;[4 \mathrm{C} 2 \mathrm{NP}]_{o}=12 \mathrm{mg} / \mathrm{L}$ 
carbon mineralization was much lower than the degree of nitrogen mineralization. Up to at least 99.01\% ( $\mathrm{pH}=3)$, 99.71\% $(\mathrm{pH}=7)$ and $99.83 \%(\mathrm{pH}=9)$ degradation of 4C2NP the 6.69\% (pH3.0), 8.14\% ( $\mathrm{pH} 7.0$ ), and $15.89 \%$ (pH 9.0) removal of TOC.

Rate constants for the degradation of 4C2NP at different $\mathrm{pHs}$

The reaction of ozone with a solute $\mathrm{M}$ may be described by the following reaction scheme:

$\mathrm{M}+\mathrm{O}_{3} \quad \mathrm{M}_{\text {oxid }}$

In practice, it is usually assumed that the Ozone reaction is first order with respect to Ozone and solute $\mathrm{M}$ concentration, thus the rate law can be formulated as:

$\underset{d t}{d[\mathrm{M}]}=k_{M}\left[\mathrm{O}_{3}\right][\mathrm{M}]$

Where, $k_{M}$ is the rate constant for the degradation of solute $\mathrm{M}$ by $\mathrm{O}_{3}$. Previous work by the authors (Chu and Wong, 2003) has confirmed that under conditions where the Ozone concentration can be considered constant, the degradation of organic compound is first order with respect to its concentration. Thus, the degradation of 4C2NP was found to follow a pseudofirst-order reaction (Fig. 6). It is well known that the oxidizing ability of ozone comes from molecular either Ozone or hydroxyl free radicals (Beltran et al., 1998).

Eq. 1, therefore, can theoretically interpret the decay rate of 4C2NP:

$$
d[4 \mathrm{C} 2 \mathrm{NP}]=\mathrm{KO}_{3}[4 \mathrm{C} 2 \mathrm{NP}]\left[\mathrm{O}_{3}\right]+k_{\mathrm{OH}}[4 \mathrm{C} 2 \mathrm{NP}]\left[\mathrm{OH}^{\circ}\right]
$$

Where, [4C2NP] is the concentration of 4C2NP in the solution, $\left[\mathrm{O}_{3}\right]$ and $\left[\mathrm{OH}^{\circ}\right]$ are the concentrations of ozone and hydroxyl radicals, $K_{O}$ and $k_{\mathrm{OH}}$ are the corresponding rate constants. Since the ozone supply in studied system was presumably in excess, a pseudosteady state condition can be assumed, that is the concentration of ozone and hydroxyl free radicals were close to constant. Eq. 1, therefore, can be rearranged as the following pseudo- first-order equation:

Where, $k$ is the overall pseudo-first-order rate constant:

$$
\underline{d[4 \mathrm{C} 2 \mathrm{NP}\rfloor}=\left(\mathrm{KO}_{3}\left[\mathrm{O}_{3}\right]+k_{\mathrm{OH}}\left[\mathrm{HO}^{\circ}\right]\right)[4 \mathrm{C} 2 \mathrm{NP}]=-k[4 \mathrm{C} 2 \mathrm{NP}]
$$

The degradation rates were shown to be $\mathrm{pH}$ dependent (Fig. 6). The decay rate increased with each increment of $\mathrm{pH}$. It was well known that the selfdecomposition of ozone would be faster at a higher concentration of hydroxide ions, i.e. at elevated $\mathrm{pH}$ and this would generate more hydroxyl free radicals, which have a much stronger oxidizing ability than that of molecular Ozone (Stockinger et al., 1995). Gurol and Vatistas (1987) reported that, beyond some critical $\mathrm{pH}$, hydroxyl radical might become the predominant oxidizing species. The rate constants shown in Table 1 indicate that the reactivity of 4C2NP is much greater at basic $\mathrm{pH}$ than at low $\mathrm{pH}$; this can also be seen in Fig. 6 . This is partly explained by the much lower reactivity of undissociated 4C2NP with molecular Ozone than in its substantially dissociated state at $\mathrm{pH} 7$ and partly by the effect of hydroxyl radical-reactions at pH 9.

\section{Degradation intermediates}

The MS analysis of intermediates of 4C2NP ozonation showed positive ion peaks at $\mathrm{m} / \mathrm{z} 129$. This indicated that product degradation of 4C2NP may be p-chlorophenol $(\mathrm{M}=128)$.

\section{CONCLUSION}

The ozonation of 4C2NP follows pseudo-first-order kinetics; its reaction rates are dominated mainly by initial $\mathrm{pH}$ level. In acidic conditions, 4C2NP removal is mainly dominated by direct oxidation by molecular ozone, while in basic conditions; indirect radical's oxidation is predominant and results in a faster decay. At $\mathrm{pH}$ 9, ozonation achieved an $99.64 \%$ degradation of 4C2NP (initial 5 min of ozonation). An increase in the $\mathrm{pH}$ values of initial solution led to higher ozonation rates as $4 \mathrm{C} 2 \mathrm{NP}$ was being treated. Degradation rate constants for 4C2NP by ozone have been determined directly at $\mathrm{pH} 3,7$ and 9 . The rate constant has been

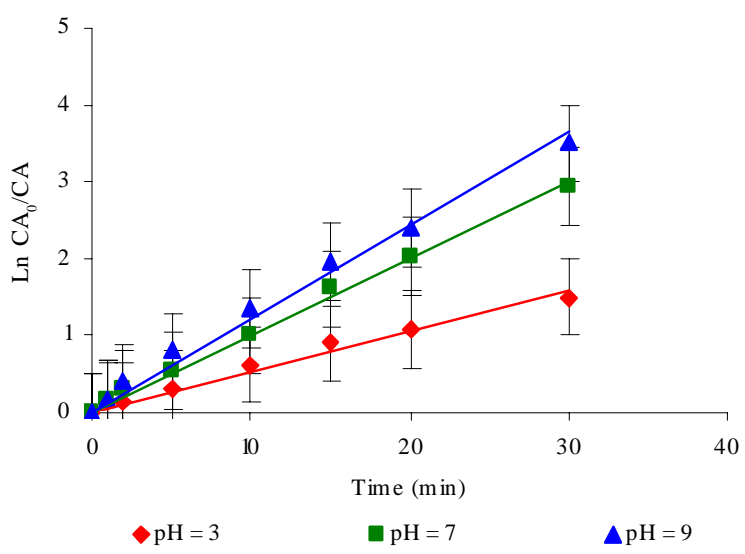

Fig. 6: Pseudo First-order decay of $12 \mathrm{mg} / \mathrm{L} 4 \mathrm{C} 2 \mathrm{NP}$ by 5.64 $\mathrm{mg} / \mathrm{L}$ ozone at various initial $\mathrm{pH}$ levels. $[\mathrm{O} 3]_{o}=5.64 \mathrm{mg} / \mathrm{L} ;[4 \mathrm{C} 2 \mathrm{NP}]_{o}=12 \mathrm{mg} / \mathrm{L}$ 
Table 1: Rate constants for 4C2NP

\begin{tabular}{lc}
\hline $\mathrm{pH}$ & $\mathrm{k}_{\mathrm{M}}^{\prime} / \mathrm{s}$ \\
\hline 3 & $8.9 \times 10^{-4}$ \\
7 & $1.67 \times 10^{-3}$ \\
9 & $2.02 \times 10^{-3}$ \\
\hline
\end{tabular}

found to increase at the higher $\mathrm{pH}$ owing to the greater reactivity of the dissociated $4 \mathrm{C} 2 \mathrm{NP}$ and the contribution of Ozone radical oxidation. The relatively small increase in 4C2NP degradation rate might be explained by the greater reactivity of the dissociated 4C2NP via the direct molecular ozone mechanism. From this study, it may be concluded that the $\mathrm{pH}$ is crucial parameter that influence 4C2NP removal by ozonation. Alkaline conditions favor the ozonation rate of the 4C2NP, since hydroxyl radical reactions are the main route of 4C2NP degradation. The main by product of degradation may be chlorophenol. In view of these experimental results, we can conclude that ozonation could be an appropriate method for the removal of 4C2NP from its aqueous solutions.

\section{ACKNOWLEDGEMENTS}

The authors thank the financial support of the School of Pharmacy, Tabriz, Iran, specially Dr. Hamidi and Miss. Faridi for their cooperation.

\section{REFERENCES}

Alaton, I. A.; Balcioglu, I. A., (2001). Photochemical and heterogeneous photocatalytic degradation of waste vinyl sulphone dyes: A case study with hydrolyzed Reactive Black 5. J. Photochem. Photobiol. A, 141 (2-3), 247-254 (8 pages).

Andrews, S. A.; Huck, P. M.; Coutts R. T., (1993). Quantitation of ozonation by-products of fractionated aquatic natural organic matter. Worn. Wasser., 81 (2), 151-165 (15 pages).

Beltran, F. J.; Encinar, J. M.; Alonso, M. A., (1998). Nitroaromatic hydrocarbon ozonationin water. 1. Single ozonation. Ind. Eng. Chem. Res., 37 (1), 25-31 (7 pages).

Benitez, F. J., (2003). Ozone reaction kinetics for water and wastewater systems, $1^{\text {st. }}$ Ed. Lewis Publishers, 124.

Benitez, F. J.; Beltran-Heredia, J.; Acero, J. L.; Rubio, F. J., (2000). Rate constants for the reactions of ozone with chlorophenols in aqueous solutions. J. Hazard. Mater. B, 79 (3), 271-285 (15 pages).

Chu, W.; Wong, C. C., (2003). A disappearance model for the prediction of trichlorophenol ozonation. Chemosphere, 51 (4), 289-294 (6 pages).

Diwani, G. E.; Rafie, S. E.; Hawash, S., (2009). Degradation of 2,4,6-trinitrotoluene in aqueous solution by ozonation and multi-stage ozonation biological treatment. Int. J. Environ. Sci. Tech., 6 (4), 6 19-628 (10 pages).

Gharbani, P.; Tabatabaii, S. M.; Mehrizad, A., (2008). Removal of Congo red from textile wastewater by ozonation. Int. J. Environ. Sci. Tech., 5 (4), 495-500 (6 pages).
Giri, R. R.; Ozaki, H.; Taniguchi, S.; Takanami, R., (2008). Photocatalytic ozonation of 2, 4-dichlorophenoxyacetic acid in water with a new $\mathrm{TiO}_{2}$ fiber. Int. J. Environ. Sci. Tech., 5 (1), 17-26(10 pages).

Goi, A.; Trapido, M.; Tuhkanen, T., (2004). A study of toxicity, biodegradability and some by-products of ozonised nitrophenols. Ad. Environ. Res., 8 (3-4), 303-311(9 pages).

Graham, N.; Chu, W.; Lau, C., (2003). Observations of 2, 4, 6trichlorophenol degradation by Ozone. Chemosphere, 51 (4), 237-243 (7 pages).

Gunten, U. V.; (2003). Ozonation of drinking water.Part 1. Oxidation kinetics and product formation. Water. Res., 37 (7), 1443-1467(25 pages).

Gurol, M. D.; Vatistas, R., (1987). Oxidation of phenolic compounds by ozone and ozone + UV radiation: A comparative study. Water Res., 21 (8), 895-900 (6 pages).

Hoigne, J., (1998). Chemistry of aqueous ozone and transformation of pollutants by ozonation and advanced oxidation processes, in: Hrubec, J. (Eds.), The Handbook of Environ. Chem. Springer-Verlag., Berlin.

Hoigne, J.; Bader, H., (1983). Rate constants of reactions of ozone with organic and inorganic compounds in water I. Water Res., 17 (2), 173-183 (11 pages).

Hong, P. K. A.; Zeng, Y., (2002). Degradation of pentachlorophenol by ozonation and biodegradability of intermediates. Water Res., 36 (17), 4243-4254 (12 pages).

Huang, W. H.; Fang, G. G.; Wang, C. C., (2005). A nanometer$\mathrm{ZnO}$ catalyst to enhance the ozonation of 2,4,6trichlorophenol in water. Colloids Surf. A, 260 (1), 45-51 (7 pages).

Kasprzyk-Hordern, B.; Ziolek, M.; Nawrocki, J., (2003). Catalytic ozonation and methods of enhancing molecular ozone reactions in water treatment. Appl. Catal. B: Environ., 46 (4), 639-669 (31 pages).

Kuo, C. H.; Huang, C. H., (1995). Aqueous phase ozonation of chlorophenols. J. Hazard. Mater., 41 (1), 31-45 (15 pages).

Legube, B.; Karpel, N. V. L., (1999). Catalytic ozonation: a promising advanced oxidation technology for water treatment. Catal. Today, 53 (1), 61-72 (12 pages).

Legube, B.; Langlais, B.; Sohm, B.; Dor, M., (1981). Identification of ozonation by-products of aromatic hydrocarbon micropollutants: Effect on chlorination and biological filtration. Ozone Sci. Eng., 3 (1), 33-48 (16 pages).

Madukasi, E. I.; Dai, X.; He, C.; Zhou J., (2010). Potentials of phototrophic bacteria in treating pharmaceutical wastewater. Int. J. Environ. Sci. Tech., 7 (1), 165-174 (10 pages).

Muthukumar, M.; Sargunamani, D.; Selvakumar, N.; Rao, V. J., (2004). Optimization of ozone treatment for color and COD removal of acid dye effluent using central composite design experiment. Dyes Pigments, 63 (2), 127-134 (8 pages).

Panjeshahi, M.H.; Ataei, A., (2008). Application of an environmentally optimum cooling water system design in water and energy conservation. Int. J. Environ. Sci. Tech., 5(2), 251-262 (12 pages).

Samarghandi, M. R.; Nouri, J.; Mesdaghinia, A. R.; Mahvi, A. H.; Nasseri, S.; Vaezi, F., (2007). Efficiency removal of phenol, lead and cadmium by means of $\mathrm{UV} / \mathrm{TiO}_{2} / \mathrm{H}_{2} \mathrm{O}_{2}$ processes. Int. J. Environ. Sci. Tech., 4 (1), 19-25 (7 pages).

Sarasa, J.; Roche, M. P.; Ormad, M. P.; Gimeno, E.; Puig, A.; Ovelleiro, J. L., (1998). Treatment of a wastewater resulting 
from dyes manufacturing with ozone and chemical coagulation. Water Res., 32 (9), 2721-2727 (7 pages).

Saritha, P.; Aparana, C.; Himabindu, V.; Anjaneyulu, Y., (2007). Advanced oxidation of 4-chloro-2-nitrophenol (4C-2NP) - A comparative study. J. Hazard. Mater., 149 (3), 609-614 (6 pages).

Sauleda, R.; Brillas, E., (2001). Mineralization of aniline and 4-chlorophenol in acidic solution by ozonation catalyzed with $\mathrm{Fe}^{2+}$ and UVA light. Appl. Catal. B: Environ., 29 (2), 135-145 (11 pages).

Shen, J. M.; Chen, Z. L.; Xu, Z. Z.; Li, X. Y.; Xu, B. B.; Qi, F., (2008). Kinetics and mechanism of degradation of pchloronitrobenzene in water by ozonation. J. Hazard. Mater., 152 (3), 1325-1331 (7 pages).

Song, S.; Xia, M.; He, Z.; Ying, H.; Lu, B.; Chen, J., (2007). Degradation of p-nitrotoluene in aqueous solution by ozonation combined with sonolysis. J. Hazard. Mater., 144 (1-2), 532-537 (6 pages).
Stockinger, H.; Heinzle, E.; Kut, O. M., (1995). Removal of chloro and nitro aromatic wastewater pollutants by ozonation and biotreatment. Environ. Sci. Tech., 29 (8), 2016-2022 (7 pages).

Utsumi, H.; Han, Y. H.; Ichikawa, K., (2003). A kinetic study of 3-chlorophenol enhanced hydroxyl radical generation during ozonation. Water Res., 37 (20), 4924-4928 (5 pages).

Villaseñor, J.; Reyes, P.; Pecchi, G., (2002). Catalytic and photocatalytic ozonation of phenol on $\mathrm{MnO}_{2}$ supported catalysts. Catal. Today, 76 (2), 121-131(11 pages).

Wu, J.; Rudya, K.; Sparka, J., (2000). Oxidation of aqueous phenol by ozone and peroxidase. Adv. Environ. Res., 4 (4), 339-346 (8 pages).

Zareen, K.; Anjaneyulu, Y., (2005). Influence of soil components on adsorption -desorption of hazardous organic-development of low cost technology for reclamation of hazardous waste dumpsites. J. Hazard. Mater. B, 118 (13), 161-169 (9 pages).

AUTHOR (S) BIOSKETCHES

Gharbani, P., Ph.D. Candidate, Department of Chemistry, North Tehran Branch, Islamic Azad University, Tehran, Iran.

Email: parvingharabani@yahoo.com

Khosravi, M., Ph.D., Lecturer, Department of Chemistry, Islamic Azad University, North Tehran Branch, Tehran, Iran.

Email:dr.m.khosravi@hotmail.com

Tabatabaei, S. M., Ph.D., Lecturer, Department of Chemistry, Islamic Azad University, Ahar Branch, Ahar, Iran.

Email:samad_tabatabaei@yahoo.com

Zare, K., Ph.D., Lecturer, Department of Chemistry, Science and Research Branch, Islamic Azad University, Tehran, Iran.

Email: info@dr-karimzare.com

Dastmalchi, S., Ph.D., Associate Professor, Biotechnology Research Center and School of Pharmacy, Tabriz University of Medical Sciences, Tabriz, Iran. Email: dastmalchi.s@tbzmed.ac.ir

Mehrizad, A., Ph.D. Candidate, Department of Chemistry, Science and Research Branch, Islamic Azad University, Tehran, Iran, and is a lecturer in the Department of Chemistry, Islamic Azad University, Ahar Branch, Ahar, Iran, Email: ali.mehrizad@yahoo.com

How to cite this article: (Harvard style)

Gharbani, P.; Khosravi, M.; Tabatabaei, S. M.; Zare, K.; Dastmalchi, S.; Mehrizad, A., (2010). Degradation of trace aqueous 4-chloro2-nitrophenol occurring in pharmaceutical industrial wastewater by ozone. Int. J. Environ. Sci. Tech., 7 (2), 377-384. 